\title{
REIT Momentum and the Performance of Real Estate Mutual Funds
}

\author{
Jeroen Derwall, Joop Huij, Dirk Brounen, and Wessel Marquering
}

\begin{abstract}
REITs exhibit a strong and prevalent momentum effect that is not captured by conventional factor models. This REIT momentum anomaly hampers proper judgments about the performance of actively managed REIT portfolios. In contrast, a REIT momentum factor adds incremental explanatory power to performance attribution models for REIT portfolios. Using this factor, this study finds that REIT momentum explains a great deal of the abnormal returns that actively managed REIT mutual funds earn in aggregate. Accounting for exposure to REIT momentum also materially influences cross-sectional comparisons of the performances of REIT mutual funds. This study has important implications for performance evaluation, alpha-beta separation, and manager selection and compensation.
\end{abstract}

A lthough real estate used to be an exclusive investment alternative for a relatively small group of investors, investing in real estate through REITs, real estate mutual funds, and private offerings is now easier than ever. Managers of such real estate portfolios as real estate mutual funds are compensated for the return they produce on their portfolios relative to that of a benchmark portfolio. The difference between the return earned by the mutual fund manager and the return on the benchmark-known as abnormal return, or alpha-is attributed to managerial skill. The benchmark return can be obtained from a factor model that is assumed to describe the crosssection of expected returns. Using such a factor model thereby ensures that the manager does not receive compensation for exposures to common factors. Fama and French $(1992,1993,1996)$ and Carhart (1997) advocated factor models composed of proxies for market risk, size and book-to-market premiums, and momentum to describe the crosssection of returns on common stocks. Researchers routinely use these factors when studying the performance of broadly diversified and actively managed equity mutual funds. ${ }^{1}$

Jeroen Derwall is assistant professor of finance at Maastricht University and at Tilburg University, the Netherlands. Joop Huij is assistant professor of finance at RSM Erasmus University and senior researcher at Robeco, Rotterdam, the Netherlands. Dirk Brounen is professor of finance and real estate at RSM Erasmus University, Rotterdam, the Netherlands. Wessel Marquering is quantitative researcher/risk manager at Taler Asset Management Ltd., Gibraltar.
Less consensus exists regarding whether these factors suffice as an evaluation of such industryspecific portfolios as REIT mutual funds or what alternative factors might be needed. The choice of factor model can substantially influence the performance attributed to active portfolio management. ${ }^{2}$ The essence of the problem is that alpha estimated with incomplete factor specifications may reflect exposure to omitted factors instead of the portfolio manager's security selection skill. Some researchers have suggested that factor models originally introduced for a wide range of common stocks inadequately describe the expected returns of portfolios that concentrate on various capital market segments. For example, Fama and French (1997) showed that conventional factor models do not suffice to describe the returns on certain industry portfolios.

We studied the REIT industry to see whether momentum effects in U.S. REIT returns can influence both the validity of common factor models and portfolio performance attribution. We were motivated to focus on REIT portfolios by recent evidence from Chui, Titman, and Wei (2003b). They demonstrated that a basic REIT-specific momentum strategy, which buys REITs with the highest past return and sells short REITs with the lowest past return, produces a return that is economically larger than that of the Jegadeesh and Titman (1993) commonstock momentum strategy. Moreover, REITs have generally been ignored in studies of the determinants of stock returns (see, e.g., Fama and French 1993). A natural question that emerges is whether REIT momentum is significantly underestimated 
by conventional factor models that control for common-stock momentum, such as the Carhart (1997) model. This potential misspecification might have important implications for existing views on the benefits of active real estate portfolio management, which stem from studies that rely on these models (see, e.g., Kallberg, Liu, and Trzcinka 2000).

\section{The Literature}

Our research was inspired by a large number of studies that explored patterns in REIT returns and by studies that built on those patterns to develop factor models that can be used to evaluate the performance of REIT portfolios. What emerged from those studies is a case for using multiple factors to describe expected REIT returns. But researchers have yet to reach a consensus on which set of factors best describes REIT returns.

Consistent with the notion that REIT returns are driven by factors not captured by aggregate stock market dynamics, Titman and Warga (1986) reported that risk-adjusted REIT returns are generally much higher under the capital asset pricing model (CAPM) that includes a value-weighted stock market proxy than under a multi-index model extracted from factor analysis. Follow-up studies (see, e.g., Chan, Hendershott, and Sanders 1990; Karolyi and Sanders 1998) recommended multifactor models in the tradition of the intertemporal CAPM (ICAPM) of Merton (1973) and the arbitrage pricing theory (APT) of Ross (1976).

More-recent research assigns considerable importance to company-specific variables as candidate factors for explaining the cross-section of REIT returns. Chen, Hsieh, Vines, and Chiou (1998) found that the cross-section of REIT returns is better explained by stock market beta and by Fama-French (1992) company-specific variables (i.e., company size and book-to-market) than by macroeconomic variables similar to those in Chen, Roll, and Ross (1986). Of the company-specific variables, size is the main robust cross-sectional determinant of REIT returns over the 1978-94 sample period. This evidence for the importance of company-specific variables in explaining the crosssection of expected REIT returns prompted the creation of intertemporal asset pricing models. Peterson and Hsieh (1997) suggested that time variation in (aggregate) equity REIT returns is best explained by the three-factor model of Fama and French (1993), which extends the equity CAPM with factor returns concerning company size and the book-to-market ratio. They concluded that equity REITs earned positive abnormal returns over the period 1976-1992 under the single-factor
CAPM and zero abnormal returns under a model with the three Fama-French (1993) factors. Consistent with the evidence of abnormal REIT returns, Hartzell, Mühlhofer, and Titman (2007) reported that including benchmarks that are sensitive to company size, book-to-market ratios, and nonREIT returns materially affects conclusions about REIT portfolio performance.

Although the Fama-French (1993) model appears to do a good job of explaining equity REIT returns, recent studies have created an appetite for a replacement model. Chui, Titman, and Wei (2003a) showed that most of the previously mentioned company-specific variables are not robust cross-sectional determinants of REIT returns over time; rather, REIT momentum is the variable that consistently explains REIT returns. According to Chui, Titman, and Wei (2003b), past REIT return is a significant driver of future REIT return both before and after 1990. Furthermore, they showed that the Fama-French (1993) model cannot explain the returns of momentumsorted REIT portfolios-similar in spirit to the momentum-sorted common-stock portfolios discussed in Jegadeesh and Titman (1993). These findings suggest that using a factor model that incorporates momentum, such as the Carhart (1997) model, might be necessary in evaluating the performance of REIT portfolios. None of the cited studies, however, investigated whether REIT momentum is explained by common-stock momentum or presented a factor model that helps capture this industry-specific anomaly.

The potential misspecification of factor models can affect existing views on the value added by REIT portfolio managers (see, e.g., Buttimer, Hyland, and Sanders 2005). Damodaran and Liu (1993) suggested that investment managers in the real estate sector produce positive abnormal returns because of their appraisal skills and their information about real estate investment targets. Supporting the active management argument of Damodaran and Liu (1993), Kallberg, Liu, and Trzcinka (2000) reported positive abnormal returns for REIT mutual funds for the period 1986-1998 under both single-factor models that include either the S\&P 500 Index or a REIT index and multifactor models that augment the single-factor model with the Fama-French (1993) factors, a bond index, and a real estate index. But none of the performance attribution models incorporate REIT momentum. Whether a REIT momentum effect underlies current conclusions about REIT mutual fund performance is a major focus of our study. 


\section{Measuring the Performance of REIT Portfolios}

Actively managed portfolios are typically evaluated by the return they generate in excess of the expected return on a passive benchmark portfolio of similar risk:

$$
\alpha_{p}=R_{p}-E\left(R_{p}\right)
$$

where $\alpha_{p}$ is Jensen's (1969) alpha, $R_{p}$ denotes the average return on portfolio $p$ over a specified investment horizon, and $E\left(R_{p}\right)$ indicates the average expected return on portfolio $p$ with factor exposures that match those of the evaluated portfolio. A positive alpha indicates that the portfolio manager has investment skills. In the context of REIT portfolios, the expected return can be determined with a linear REIT factor model:

$$
\begin{aligned}
E\left(R_{p, t}\right)= & \gamma_{p}+\beta_{1, p} X_{1, t}+\beta_{2, p} X_{2, t} \\
& +\ldots+\beta_{K, p} X_{K, t},
\end{aligned}
$$

where $E\left(R_{p, t}\right)$ is the expected return on portfolio $p$ at time $t, \beta_{K, p}$ is portfolio $p^{\prime}$ s exposure to factor $K$ $(K=1,2, \ldots, K)$, and $X_{K, t}$ is the return on factor $K$ at time $t$. Note that the estimates of the parameters in Equation 2 are assumed to be time-invariant for expositional convenience.

We can interpret REIT models that include a mixture of factors along several lines. One interpretation is that these models are similar to multifactor models for common stocks. Theoretically, these models can be justified by various alternatives to the CAPM, such as the ICAPM of Merton (1973) and the APT of Ross (1976). In this setup, the factors are proxies for underlying risks in the economy that are of concern to investors. Usually, factors are measured as factor-mimicking return spreads (e.g., between a passive benchmark and the risk-free rate of return), and the models' betas measure the funds' risk-factor exposures. An alternative interpretation is that the factors compose a performance attribution model that essentially controls for passive investment return, as in Carhart (1997), where the passive benchmarks multiplied by their estimated weights (betas) most closely reproduce a fund's return variation. The excess return (Jensen's alpha in Equation 1) measures portfolio management skill only if the performance attribution model captures all factors that drive REIT returns or accounts for all possible abnormal returns that can be earned by pursuing certain investment styles. ${ }^{3}$ Whether the misspecification problem plagues REIT performance evaluation is addressed throughout this article.
The models central to our study arose from a large body of research on factors affecting common stocks (see, e.g., Fama and French 1992, 1993, 1996, 1997; Jegadeesh and Titman 1993; Carhart 1997; and Moskowitz and Grinblatt 1999) and from studies on variables that explain returns on real estate securities (see, e.g., Smith and Shulman 1976; Peterson and Hsieh 1997; Chui, Titman, and Wei 2003a, 2003b). These models are also found in earlier research on REIT mutual fund performance (see, e.g., Kallberg, Liu, and Trzcinka 2000; Lin and Yung 2004).

The first model we consider is a single-factor model in the tradition of the CAPM of Sharpe (1964), Lintner (1965), and Mossin (1966), in which the expected return on a portfolio is a function of the portfolio's systematic risk. The estimated version of the CAPM that we use predicts the following relationship between beta and expected return:

$$
E\left(R_{p, t}\right)=R_{f, t}+\beta_{1, p}\left(R_{m, t}-R_{f, t}\right),
$$

where $R_{f, t}$ is the risk-free rate at time $t$ and $R_{m, t}$ is the return on the stock market at time $t$.

The second model accounts for activities in the real estate sector. The model predicts a similar relationship between beta and expected return as in Equation 3, but the return on the REIT market is used instead of the return on the stock market.

The third model is the three-factor model of Fama and French (1993), who documented that $\beta_{1, p}$ alone inadequately describes the cross-section of returns on stock portfolios formed on market capitalization and book-to-market. Because evidence suggests that company size and book-to-market may be cross-sectional determinants of REIT returns (see, e.g., Chui, Titman, and Wei 2003a), the Fama-French factors could represent a legitimate expected return model for REITs:

$$
\begin{aligned}
E\left(R_{p, t}\right)= & R_{f, t}+\beta_{1, p}\left(R_{m, t}-R_{f, t}\right) \\
& +\beta_{2, p} S M B_{t}+\beta_{3, p} H M L_{t},
\end{aligned}
$$

where $S M B_{t}$ is the return difference between a small-cap stock portfolio and a large-cap stock portfolio at time $t$ and $H M L_{t}$ is the return difference between a high-book-to-market stock portfolio and a low-book-to-market stock portfolio at time $t$.

Our fourth model is the four-factor model originally introduced by Carhart (1997). In response to evidence that the Fama-French (1993) model fails to capture the returns of Jegadeesh and Titman's (1993) momentum strategy, Carhart proposed a four-factor model that augments the three-factor specification with a momentum factor. In addition, Chui, Titman, and Wei (2003b) determined that price momentum is a cross-sectional determinant 
of REIT returns by controlling for other companyspecific factors, such as size and book-to-market. This model takes the following form: ${ }^{4}$

$$
\begin{aligned}
E\left(R_{p, t}\right)= & R_{f, t}+\beta_{1, p}\left(R_{m, t}-R_{f, t}\right)+\beta_{2, p} S M B_{t} \\
& +\beta_{3, p} H M L_{t}+\beta_{4, p} W M L_{t},
\end{aligned}
$$

where $W M L_{t}$ is the return difference between a common-stock portfolio with high past returns and a common-stock portfolio with low past returns at time $t$.

To develop these models, we used stock and T-bill rate data from French (2008) and data on REITs from the CRSP/Ziman Real Estate Data Series. Arguably the most complete source of REIT data, the CRSP/Ziman Real Estate Data Series includes all REITs that have been traded on the NYSE, Amex, and NASDAQ since 1980. Following the majority of related studies, we defined $R_{m, t}$ as the monthly returns on a value-weighted portfolio comprising all NYSE-Amex-NASDAQ stocks. We used the one-month T-bill rate from Ibbotson Associates as a proxy for the risk-free rate $\left(R_{f, t}\right)$. The construction of the factor-mimicking portfolios related to size and book-to-market effects $\left(S M B_{t}\right.$ and $\left.H M L_{t}\right)$ and of the common-stock momentum factor $\left(W M L_{t}\right)$ is described in Fama and French (1993) and French (2008). Finally, we collected REIT data from the CRSP / Ziman Real Estate Data Series to develop our measure of aggregate REIT return $\left(V W R E I T_{t}\right)$, which we defined as the value-weighted return on all available REITs. We required each REIT to have at least 12 consecutive return observations in order to be included in our dataset.

Our inspection of the factors produced several observations. Over the entire sample period, the REIT market earned a relatively high premium. The annual average excess REIT return (6.65 percent) is similar to the annual average excess return on the stock market (6.55 percent). Consistent with Ross and Zisler (1991), we observed that the REIT market correlates with common-stock portfolios. For example, we found that the monthly return on a value-weighted portfolio of all REITs traded on the NYSE-Amex-NASDAQ correlates positively with the value-weighted portfolio comprising all NYSE-Amex-NASDAQ stocks (a correlation of 0.55). The correlations also indicate that REITs fall on the high end of the company size (SMB) and value (HML) spectrums, which is in line with important REIT characteristics: REITs are typically small or midsize companies that pay out relatively high dividends (REITs are legally required to distribute at least 90 percent of their taxable income to shareholders annually in the form of dividends). Furthermore, REITs generally have high book-to- market values because they hold mostly tangible assets in the form of real estate, consistent with their behaving like value stocks that correlate positively with the HML factor (in contrast to, e.g., IT companies, which usually have low book-to-market ratios and negative exposure to HML).

\section{The REIT Momentum Effect}

Starting with Jegadeesh and Titman (1993), a substantial body of research in the area of common stocks has documented economically large returns on a strategy that buys past-12-month-return winners and sells short past losers. In the area of common stocks, momentum returns have posed a great challenge to asset pricing models because evidence shows that momentum returns cannot be explained by market beta or by the size and book-to-market effects on returns. Carhart (1997) captured marketwide momentum profits by using a four-factor model that extends the Fama-French factors with a stock-momentum factor.

Prior evidence suggests that momentum effects are also prevalent in the REIT industry. Chui, Titman, and Wei (2003a) demonstrated that past REIT returns are a consistently accurate predictor of future REIT returns, and Chui, Titman, and Wei (2003b) reported that REIT momentum profits are stronger than momentum effects in other U.S. industries. Therefore, we reexamined the strength and prevalence of REIT momentum for our sample period and tested whether the conventional factors central to our study suffice to capture REIT momentum profits.

We examined momentum in REIT portfolio returns by studying all U.S. equity REITs in the CRSP/Ziman Real Estate Data Series over the period January 1980-September 2008. For every month in our sample period, we ranked all available REITs by their past-11-month returns (one-month lagged) and grouped them into equally weighted tercile portfolios. We then evaluated the REIT portfolios' postformation returns for the following month by using the single-, three-, and four-factor performance attribution models, and we performed a GRS (Gibbons, Ross, and Shanken 1989) test to determine whether the returns on momentumsorted REIT portfolios can be fully described by exposures to the factors in the models. ${ }^{5}$ The GRS test is underpinned by the simple condition that an accurately specified factor model leave no cross-sectional variation in returns unexplained; so, all alphas have an expected value of zero. In other words, we formally tested the hypothesis that the portfolios' alphas are jointly indistinguishable from zero. 
Table 1 presents the returns of momentumsorted REIT portfolios on the basis of 11-month returns (one-month lagged) for various postformation periods. The results indicate that REITs that did well in the past continue to do so in the future, consistent with a REIT momentum effect. The postformation return on the top-ranked REIT tercile portfolio is more than twice as large as the return on its bottom-ranked counterpart. The results also indicate that REIT momentum is prevalent up to 15 months after formation. Jegadeesh and Titman (1993) reported that momentum strategies for common stocks are anomalously profitable for holding periods of 3-12 months. Therefore, we conclude that REITs exhibit a strong and prevalent momentum effect.

With respect to the ability of conventional factor models to explain REIT momentum, Table 2 shows the returns on momentum-sorted REIT portfolios after controlling for common-stock and REIT market beta, size, book-to-market, and momentum. None of the conventional factor models can fully explain the cross-section of returns on REIT portfolios that are formed on the basis of past returns. Average risk-adjusted returns tend to decrease as tercile rank decreases, independent of any factor model specification. In addition, for all specifications, the GRS test rejects the null hypothesis that the REIT terciles jointly earn zero abnormal returns (at the conventional significance levels). Although our finding that the momentum effect is prevalent in the REIT industry confirms the results of Chui, Titman, and Wei (2003b), the most striking finding from our analysis is that the common-stock momentum factor does not suffice to capture the REIT momentum anomaly. The spread in alpha between the top tercile and the bottom tercile of REITs sorted on past returns is 6.6 percent a year under the Carhart (1997) model.

The REIT momentum effect also withstands a number of robustness tests (unreported in tabular form here). First, REIT momentum is unrelated to the REIT IPO effect. Buttimer, Hyland, and Sanders (2005) reported that REIT returns were largely driven by the returns of REIT IPOs in the 1990s. We accounted for the IPO effect by removing all initial 12 monthly returns for every REIT in our sample prior to forming the tercile portfolios. The spread in alpha between the top and bottom terciles remains economically large and statistically significant- 5.7 percent a year under the Carhart (1997) model.

Second, we investigated whether the REIT momentum effect is also observed over morerecent subperiods. With respect to the performance of the tercile portfolios of REITs over the most recent 10 years in our sample, the alpha spread between the top and bottom terciles is large and statistically significant under all four conventional factor models. Under the Carhart (1997) model, the spread equals 6.39 percent a year. Over the most recent five years in our sample, the spread equals 6.29 percent.

Third, adding the Pastor and Stambaugh (2003) liquidity risk factor to the Carhart (1997) four-factor model does not help explain crosssectional variation in abnormal tercile returns. None of the portfolios are significantly exposed to the liquidity factor, and the alpha spread between the top-and bottom-tercile portfolios continues to be significant at 6.7 percent a year.

Finally, the REIT momentum anomaly shows up with a model that corrects for autocorrelation. Because REITs invest in illiquid assets that are typically not actively traded and for which market prices are not always readily available, their reported returns tend to be smoother than true economic returns. This phenomenon understates REIT volatility and increases risk-adjusted performance measures, such as the Sharpe ratio. To incorporate this feature of REIT returns, we applied a model in the spirit of Dimson (1979) and Getmansky, Lo, and Makarov (2004) that includes lagged values of the variables in our factor models together with the original factors. After this correction is applied, the alpha spread between the top and bottom terciles remains large and statistically significant under all four conventional factor models. Under the model that includes the four Carhart (1997) factors and their lagged values, the alpha spread is 6.6 percent a year.

Table 1. Strength and Prevalence of REIT Momentum, January 1980September 2008

\begin{tabular}{llllllll}
\hline & \multicolumn{7}{c}{ Months after Formation } \\
\cline { 2 - 8 } & \multicolumn{1}{c}{0} & \multicolumn{1}{c}{3} & \multicolumn{1}{c}{6} & 9 & 12 & 15 & 18 \\
\hline P1 (top) & $9.51 \%$ & $9.51 \%$ & $9.80 \%$ & $9.85 \%$ & $10.45 \%$ & $10.67 \%$ & $8.49 \%$ \\
P2 & 8.94 & 8.23 & 6.97 & 8.92 & 6.83 & 7.02 & 9.21 \\
P3 (bottom) & 2.68 & 3.27 & 4.40 & 4.20 & 5.09 & 6.10 & 6.86 \\
Top - bottom & $6.83 \%$ & $6.24 \%$ & $5.40 \%$ & $5.66 \%$ & $5.36 \%$ & $4.57 \%$ & $1.63 \%$ \\
\hline
\end{tabular}


Table 2. Momentum-Sorted REIT Portfolios and Common-Stock Factor Models, January 1980September 2008

\begin{tabular}{|c|c|c|c|c|c|c|c|c|c|c|c|c|}
\hline & \multicolumn{3}{|c|}{ CAPM } & \multicolumn{3}{|c|}{ VWREIT } & \multicolumn{3}{|c|}{ Fama-French 3FM } & \multicolumn{3}{|c|}{ Carhart 4FM } \\
\hline & Alpha & Alpha- $t$ & Adj. $R^{2}$ & Alpha & Alpha- $t$ & Adj. $R^{2}$ & Alpha & Alpha- $t$ & Adj. $R^{2}$ & Alpha & Alpha- $t$ & Adj. $R^{2}$ \\
\hline P1 (top) & $7.12 \%$ & 3.67 & 0.25 & $4.64 \%$ & 3.89 & 0.72 & $3.36 \%$ & 1.88 & 0.41 & $3.18 \%$ & 1.73 & 0.41 \\
\hline P2 & 6.72 & 3.01 & 0.18 & 3.40 & 2.89 & 0.77 & 1.32 & 0.67 & 0.41 & 2.02 & 1.00 & 0.41 \\
\hline P3 (bottom) & -0.08 & -0.03 & 0.20 & -3.81 & -2.66 & 0.76 & -5.92 & -2.58 & 0.42 & -3.39 & -1.49 & 0.46 \\
\hline GRS & & 7.43 & & & 6.97 & & & 5.71 & & & 3.17 & \\
\hline ( $p$-Value) & & $(0.00)$ & & & $(0.00)$ & & & $(0.00)$ & & & $(0.00)$ & \\
\hline
\end{tabular}

Notes: This table reports the returns of momentum-sorted REIT portfolios on the basis of 11-month returns (one-month lagged). The returns are evaluated by using the CAPM with a common-stock market factor and with a REIT market factor (VWREIT), the Fama-French three-factor model (3FM), and the Carhart four-factor model (4FM). The table presents alphas with $t$-statistics (alpha- $t$ ), adjusted $R^{2}$ (adj. $R^{2}$ ), and the GRS test statistic with $p$-values to determine whether the returns can be fully described by exposures to the factors in the models.

\section{Practical Implications: A New Model to Measure Real Estate Mutual Fund Performance}

Thus far, our findings suggest that investors can follow a basic REIT momentum strategy and produce returns that are not fully explained by conventional factor models. Because the superior return on REIT momentum portfolios-relative to that on common-stock momentum portfolioscould mask the true value added by active REIT management under conventional factor models, we investigated whether this misspecification problem affects REIT mutual fund performance.

The obvious question is whether REIT mutual fund performance is tied to REIT momentum. To examine this issue, we constructed a REIT momentum factor by taking the differential return between the top- and bottom-ranked REIT tercile portfolios. The new factor model takes the following form:

$$
\begin{aligned}
E\left(R_{p, t}\right)= & R_{f, t}+\beta_{1, p}\left(R_{m, t}-R_{f, t}\right)+\beta_{2, p} S M B_{t} \\
& +\beta_{3, p} H M L_{t}+\beta_{4, p} \text { REITWML }_{t},
\end{aligned}
$$

where REITWML $L_{t}$ is the return difference between the portfolio of REITs with high past returns and the portfolio of REITs with low past returns at time $t$.

To demonstrate the usefulness of our REIT momentum factor in evaluating performance, we first had to show its ability to explain the crosssectional variation in returns on momentumsorted REIT portfolios. Table 3 reveals that our REIT momentum factor is indeed able to do so. We found that many of the abnormal returns on the momentum-sorted tercile portfolios disappear under the Fama-French (1993) three-factor model augmented with the REIT momentum factor. Not surprisingly, the GRS test cannot reject the null hypothesis that the alphas are jointly zero. Moreover, that an increased exposure to the REIT momentum factor is associated with an increase in tercile rank supports the notion that our REIT momentum factor can explain the returns on the momentum-sorted REIT portfolios.

To examine the role of REIT momentum in explaining REIT mutual fund performance, we analyzed the returns of professionally managed investment vehicles in the form of mutual funds that hold REIT securities (i.e., REIT mutual funds).

Table 3. Momentum-Sorted REIT Portfolios and REIT Momentum, January 1980-September 2008

\begin{tabular}{lcccccccr}
\hline & \multicolumn{7}{c}{ Fama-French 3FM + REITWML } \\
\cline { 2 - 9 } & Alpha & Alpha- $t$ & RMRF & SMB & HML & REITWML & REITWML- $t$ & Adj. $R^{2}$ \\
\hline P1 (top) & $0.58 \%$ & 0.34 & 0.53 & 0.46 & 0.52 & 0.30 & 7.41 & 0.49 \\
P2 & 1.46 & 0.72 & 0.53 & 0.45 & 0.64 & -0.02 & -0.32 & 0.41 \\
P3 (bottom) & 0.58 & 0.34 & 0.53 & 0.46 & 0.52 & -0.70 & -17.32 & 0.70 \\
GRS & & 0.20 & & & & & & \\
$(p$-Value) & & $(0.90)$ & & & & & & \\
\hline
\end{tabular}

Notes: See notes to Table 2. The returns are evaluated by using the Fama-French three-factor model augmented with our REIT momentum factor (3FM + REITWML). The table presents alphas with $t$-statistics (alpha-t), factor exposures, adjusted $R^{2}$ (adj. $R^{2}$ ), and the GRS test statistic with $p$-values to determine whether the returns can be fully described by exposures to the factors in the models. 
We used data on all U.S. REIT mutual funds from the 2008 CRSP Survivor-Bias-Free U.S. Mutual Fund Database. ${ }^{6}$ The CRSP universe includes data on all U.S. mutual funds that existed between January 1962 and July 2008. We thus overcame the types of survivorship bias described in Brown, Goetzmann, Ibbotson, and Ross (1992) and Carpenter and Lynch (1999). We focused on mutual funds that were classified as investments in real estate securities. Using the Carhart (1997) model and the Fama-French (1993) model augmented with our REIT momentum factor, we estimated alphas for all funds having at least 36 consecutive monthly return observations in our sample. The resulting sample covers returns of 282 REIT mutual funds over January 1980-July 2008.

Table 4 shows that although REIT mutual funds, on average, earn an alpha of 2.98 percent under the Carhart (1997) model, the outperformance evaporates once REIT momentum is accounted for. This decline in alpha suggests that the abnormal returns that REIT mutual funds earn according to earlier studies are caused by exposure to REIT momentum.

We next investigated whether REIT momentum explains persistence in the performance of REIT mutual funds. Lin and Yung (2004) reported persistence in the performance of REIT mutual funds after correcting for several factors, including common-stock momentum. Given our findings that a common-stock momentum factor does not suffice to capture REIT momentum and that REIT mutual funds with relatively high returns tend to be more exposed to REIT momentum, we could $a$ priori expect that performance attribution that accounts for REIT momentum deepens our understanding of the potential sources of persistence in the performance of REIT mutual funds.

In our analysis of persistence in REIT mutual fund returns, for every month, we ranked and allocated all REIT mutual funds to one of three tercile portfolios on the basis of past-12-month returns, in the tradition of Hendricks, Patel, and Zeckhauser (1993). We then evaluated the postformation returns of the tercile portfolios by using the Carhart (1997) model and the model that replaces commonstock momentum with our REIT momentum factor.

Table 5 shows that the postformation return spread between the top and bottom terciles is about 4.4 percent a year. Although persistence in REIT fund returns is statistically insignificant, several observations suggest that our REIT momentum factor incrementally helps explain returns of REIT funds ranked on past return. First, the top-ranked tercile of REIT funds (P1) appears to have a relatively greater Carhart (1997) alpha than do other terciles because of a stronger and statistically significant exposure to the REIT momentum factor ( $t$-statistic of 3.17). Second, consistent with the results of Table 4, Table 5 shows that the economically large abnormal returns that REIT funds generally earn under the Carhart (1997) model are eliminated when the common-stock momentum factor is replaced with REIT momentum. The three REIT mutual fund terciles earn near zero or even negative alphas under the three-factor model with

Table 4. REIT Momentum and REIT Mutual Fund Performance, January 1980-July 2008

\begin{tabular}{|c|c|c|c|c|c|c|c|c|c|c|}
\hline & \multicolumn{5}{|c|}{ Carhart 4FM } & \multicolumn{5}{|c|}{ Fama-French 3FM + REITWML } \\
\hline & Alpha & Alpha- $t$ & WML & WML- $t$ & Adj. $R^{2}$ & Alpha & Alpha- $t$ & REITWML & REITWML- $t$ & Adj. $R^{2}$ \\
\hline Mean & $2.98 \%$ & 0.53 & -0.12 & -1.09 & 0.41 & $-0.07 \%$ & -0.05 & 0.22 & 1.35 & 0.41 \\
\hline Std. dev. & 3.99 & 0.73 & 0.14 & 0.90 & 0.10 & 3.46 & 0.72 & 0.18 & 1.05 & 0.09 \\
\hline Median & 2.87 & 0.65 & -0.06 & -0.97 & 0.39 & 0.29 & 0.05 & 0.22 & 1.59 & 0.40 \\
\hline \multicolumn{11}{|l|}{ Percentile } \\
\hline 10 & $-0.81 \%$ & -0.20 & -0.33 & -2.34 & 0.29 & $-3.93 \%$ & -0.76 & -0.01 & -0.09 & 0.32 \\
\hline 20 & 0.66 & 0.16 & -0.26 & -1.80 & 0.33 & -2.02 & -0.49 & 0.10 & 0.73 & 0.36 \\
\hline 30 & 1.56 & 0.36 & -0.14 & -1.50 & 0.35 & -1.27 & -0.31 & 0.17 & 1.06 & 0.37 \\
\hline 40 & 2.39 & 0.55 & -0.08 & -1.26 & 0.37 & -0.33 & -0.08 & 0.20 & 1.30 & 0.38 \\
\hline 50 & 2.93 & 0.66 & -0.06 & -0.98 & 0.39 & 0.30 & 0.06 & 0.22 & 1.59 & 0.40 \\
\hline 60 & 3.82 & 0.73 & -0.05 & -0.79 & 0.41 & 0.72 & 0.17 & 0.25 & 1.66 & 0.41 \\
\hline 70 & 4.89 & 0.90 & -0.04 & -0.64 & 0.43 & 1.33 & 0.27 & 0.30 & 1.88 & 0.43 \\
\hline 80 & 5.76 & 1.01 & -0.03 & -0.34 & 0.46 & 2.58 & 0.44 & 0.36 & 2.19 & 0.45 \\
\hline 90 & 7.67 & 1.18 & -0.01 & -0.07 & 0.53 & 3.62 & 0.64 & 0.43 & 2.50 & 0.50 \\
\hline
\end{tabular}

Notes: This table compares alphas of REIT mutual funds under the Carhart four-factor model (4FM) augmented with a common-stock momentum factor with alphas under the Fama-French three-factor model augmented with our REIT momentum factor (3FM + REITWML). For both models, the table presents each alpha's mean, standard deviation, and median, as well as the percentiles of each alpha's distribution. 
Table 5. REIT Momentum and Persistence in REIT Mutual Fund

Performance, January 1980-July 2008

\begin{tabular}{lccccccccc}
\hline & \multicolumn{8}{c}{ Carhart 4FM } \\
\cline { 2 - 9 } & Return & Alpha & Alpha-t & RMRF & SMB & HML & WML & WML-t & Adj. $R^{2}$ \\
\hline P1 (top) & $8.86 \%$ & $1.14 \%$ & 0.46 & 0.65 & 0.36 & 0.61 & 0.04 & 0.93 & 0.41 \\
P2 & 7.93 & 1.39 & 0.57 & 0.58 & 0.37 & 0.60 & -0.02 & -0.36 & 0.39 \\
P3 (bottom) & 4.51 & -2.30 & -1.02 & 0.66 & 0.41 & 0.62 & -0.05 & -1.27 & 0.49 \\
GRS & & & 3.58 & & & & & & \\
$(p$-Value) & & & $(0.01)$ & & & & & &
\end{tabular}

\begin{tabular}{lccccccccc} 
& \multicolumn{8}{c}{ Fama-French 3FM + REITWML } \\
\cline { 2 - 10 } & Return & Alpha & Alpha- $t$ & RMRF & SMB & HML & REITWML & REITWML- $t$ & Adj. $R^{2}$ \\
\hline P1 (top) & $8.86 \%$ & $-0.12 \%$ & -0.05 & 0.68 & 0.40 & 0.67 & 0.18 & 3.17 & 0.44 \\
P2 & 7.93 & -0.27 & -0.11 & 0.61 & 0.41 & 0.66 & 0.14 & 2.54 & 0.40 \\
P3 (bottom) & 4.51 & -3.62 & -1.61 & 0.68 & 0.42 & 0.66 & 0.06 & 1.18 & 0.49 \\
GRS & & & & & & & & & \\
$(p$-Value) & & & & & & & & & \\
\hline
\end{tabular}

Notes: This table presents the returns of momentum-sorted REIT mutual fund portfolios on the basis of 12 -month returns. The returns are evaluated by using the Carhart four-factor model (4FM) and the Fama-French three-factor model augmented with our REIT momentum factor (3FM + REITWML). The table presents alphas with $t$-statistics (alpha- $t$ ), factor exposures, adjusted $R^{2}$ (adj. $R^{2}$ ), and the GRS test statistic with $p$-values to determine whether the returns can be fully described by exposures to the factors in the models.

REIT momentum. Third, including the REIT momentum factor increases the $R^{2}$ of the performance attribution model for the top-ranked funds.

To further illustrate how the choice of factor model has practical implications for the evaluation of REIT mutual fund performance, Table 6 shows the extent to which the two models agree about ranking REIT mutual funds on the basis of their alphas. The main finding is that REIT momentum has a sizable influence on REIT mutual fund ranking. The Carhart (1997) model produces a ranking that is different from the one we obtain when we replace the common-stock momentum factor with our REIT momentum factor. For example, of the REIT funds that appear in the top quintile under Carhart's (1997) model, more than 40 percent move to a lower-ranked quintile when we control for REIT momentum. For all other quintile ranks, the disagreement between the two models is also strong.

Hence, our tests show that controlling for REIT momentum alters our view of REIT mutual fund performance along two lines. Exposure to REIT momentum not only explains a great deal of the abnormal performance of REIT mutual funds as a whole; it also materially affects cross-sectional rankings of those funds.

Table 6. REIT Momentum and REIT Mutual Fund Rankings, January 1980July 2008

\begin{tabular}{lccccc}
\hline & \multicolumn{5}{c}{ Fama-French 3FM + REITWML } \\
\cline { 2 - 6 } Carhart 4FM & P1 (Top) & P2 & P3 & P4 & P5 (Bottom) \\
\hline P1 (top) & $59 \%$ & $21 \%$ & $18 \%$ & $2 \%$ & $0 \%$ \\
P2 & 41 & 34 & 5 & 13 & 7 \\
P3 & 0 & 39 & 47 & 11 & 4 \\
P4 & 0 & 5 & 29 & 48 & 18 \\
P5 (bottom) & 0 & 0 & 2 & 26 & 72 \\
\hline
\end{tabular}

Notes: This table compares alpha rankings of REIT mutual funds under the Carhart four-factor model (4FM) augmented with a common-stock momentum factor with alpha rankings under the Fama-French three-factor model augmented with our REIT momentum factor (3FM + REITWML). The table shows the percentages of REIT mutual funds ranked by quintile on the basis of alphas from both models. 


\section{Conclusion}

Conventional performance attribution approaches focus on whether the returns of an actively managed portfolio can be mimicked by exposure to a set of benchmark factors. Any unexplained return is then attributed to managerial skill. Our study found that the cross-section of returns of momentum-sorted REIT portfolios is not explained by conventional factor models, which implies that abnormal returns derived from those models may mask the true value of active REIT portfolio management. Returns on momentum portfolios that are long in high-return REITs and short in low-return REITs are economically significant for up to 15 months after formation. Our study is the first to emphasize that momentum profits in the REIT industry are significantly underestimated by conventional factor models that control for beta, size, and book-to-market effects and by Carhart's (1997) common-stock momentum factor.

Because we found that the returns of REIT momentum portfolios cannot be replicated by exposure to common-stock factors, we hypothesized that residual returns of actively managed REIT portfolios might reflect exposure to an omitted REIT momentum factor instead of managerial skill. Our evaluation of U.S. REIT mutual funds suggests that this hypothesis is true. The REIT momentum factor that we incorporated into performance attribution influences REIT mutual fund alphas in two ways. First, REIT momentum plays a key role in explaining the outperformance that REIT funds as a whole display under the conventional four-factor model of Carhart (1997). The positive alphas that REITs deliver under conventional factor models dissipate under a model that includes the three Fama-French (1993) factors and a REIT momentum factor. Second, we showed that a consideration of REIT momentum affects our understanding of cross-sectional variation in the performance of REIT funds. Therefore, factoring REIT momentum into performance attribution has important consequences for the evaluation of REIT fund managers.

In essence, at least three practical implications emerge from our study. The choice of factor model clearly has important ramifications for the selection of a REIT manager, whether for a mutual fund or a private offering. Furthermore, because REIT managers appear to be providing less alpha than they have been given credit for in previous studies, relatively unsophisticated or inexperienced investors might be wise to turn to indexation. Finally, because common benchmarking models for judg- ing REIT managers are inadequate, our findings encourage a rethinking of the structure of incentive fees that are paid to REIT managers.

Several avenues for further research remain. One unanswered question concerns the nature of the momentum effect in REITs. What drives REIT momentum? No consensus on the source of the momentum effect exists. Most research seems to suggest that underreaction and overreaction of investors to good and bad news concerning company-specific information are at the root of the momentum effect. For example, Hong and Stein (1999) and Hong, Lim, and Stein (2000) found that the momentum effect is consistent with the theory of "gradual diffusion of information." They showed that especially bad news travels slowly over time. Consistent with this theory, they further showed that the profitability of a momentum strategy declines sharply with an increase in company size and that a momentum strategy is more profitable for companies with little analyst coverage. Conrad and Kaul (1998) argued that a momentum strategy's average profitability simply reflects cross-sectional variation in unconditional mean returns.

Vayanos and Woolley (2008) recently showed that money inflow in winning mutual funds and money outflow in losing mutual funds create a momentum effect because of the buying pressure in winning stocks and the selling pressure in losing stocks arising from the money flows. Often, winning mutual funds concentrate on value stocks and losing ones focus on growth stocks, and vice versa. In this case, no skill is needed to produce the winning or the losing mutual fund.

Another important issue is whether REITspecific factors other than momentum should be used to construct a factor model for REITs. For example, although several studies have indicated that REIT returns are positively correlated with size and book-to-market factors, whether the Fama and French (1993) factors suffice to fully capture size and value effects in REIT returns is unclear. Whether performance evaluation is further affected by REIT-specific size and book-to-market factors is an interesting question that awaits further research.

For their valuable comments, we thank Mathijs Cosemans, Piet Eichholtz, Martin Martens, Anthony Sanders, Peter Schotman, seminar participants at Maastricht University and the University of Grenoble, and participants at the Professional Asset Management conference at the Rotterdam School of Management.

This article qualifies for 1 CE credit. 


\section{Notes}

1. See, for example, Grinblatt and Titman (1992); Hendricks, Patel, and Zeckhauser (1993); Goetzmann and Ibbotson (1994); Brown and Goetzmann (1995); and Carhart (1997) for studies of the performance of actively managed equity mutual funds.

2. See Elton, Gruber, Das, and Hlavka (1993).

3. For example, such a model could explain the return dynamics associated with such widely researched investment styles as trading based on the size effect (Banz 1981), the book-tomarket (value) effect (Lakonishok, Schleifer, and Vishny 1994), and the momentum effect (Jegadeesh and Titman 1993).
4. For expositional convenience, we used the same notation for the beta parameters in Equations 3, 4, and 5. Note, however, that they take different values.

5. We circumvented the problem of overlapping samples by not measuring REIT momentum in terms of cumulative average returns, unlike Jegadeesh and Titman (1993).

6. Our study benefited from using a cross-section of REIT mutual funds that was larger than the cross-section examined in earlier research.

\section{References}

Banz, Rolf W. 1981. "The Relationship between Return and Market Value of Common Stocks." Journal of Financial Economics, vol. 9, no. 1 (March):3-18.

Brown, S.J., and W.N. Goetzmann. 1995. "Performance Persistence." Journal of Finance, vol. 50, no. 2 (June):679-698.

Brown, S.J., W.N. Goetzmann, R.G. Ibbotson, and S.A. Ross. 1992. "Survivorship Bias in Performance Studies." Review of Financial Studies, vol. 5, no. 4 (Winter):553-580.

Buttimer, Richard J., David C. Hyland, and Anthony B. Sanders. 2005. "REITs, IPO Waves, and Long-Run Performance." Real Estate Economics, vol. 33, no. 1 (March):51-87.

Carhart, Mark M. 1997. “On Persistence in Mutual Fund Performance." Journal of Finance, vol. 52, no. 1 (March):57-82.

Carpenter, Jennifer N., and Anthony W. Lynch. 1999. "Survivorship Bias and Attrition Effects in Measures of Performance Persistence." Journal of Financial Economics, vol. 54, no. 3 (December):337-374.

Chan, K.C., Patric H. Hendershott, and Anthony B. Sanders. 1990. "Risk and Return on Real Estate: Evidence from Equity REITs." AREUEA Journal, vol. 18, no. 4:431-452.

Chen, Nai-Fu, Richard Roll, and Stephen A. Ross. 1986. "Economic Forces and the Stock Market." Journal of Business, vol. 59, no. 3 (July):383-403.

Chen, Su-Jane, Chengho Hsieh, Timothy W. Vines, and ShurNuaan Chiou. 1998. "Macroeconomic Variables, Firm-Specific Variables and Returns to REITs." Journal of Real Estate Research, vol. 16, no. 3:269-278.

Chui, Andy C.W., Sheridan Titman, and K.C. John Wei. 2003a. "The Cross-Section of Expected REIT Returns." Real Estate Economics, vol. 31, no. 3 (September):451-479.

- 2003b. "Intra-Industry Momentum: The Case of REITs." Journal of Financial Markets, vol. 6, no. 3 (May):363-387.

Conrad, J., and G. Kaul. 1998. "An Anatomy of Trading Strategies." Review of Financial Studies, vol. 11, no. 3 (Fall):489-519.

Damodaran, A., and C.H. Liu. 1993. "Insider Trading as a Signal of Private Information." Review of Financial Studies, vol. 6, no. 1 (Spring):79-119.

Dimson, E. 1979. "Risk Measurement When Shares Are Subject to Infrequent Trading." Journal of Financial Economics, vol. 7, no. 2 (June):197-226.

Elton, E.J., M.J. Gruber, S. Das, and M. Hlavka. 1993. “Efficiency with Costly Information: A Reinterpretation of Evidence from Managed Portfolios." Review of Financial Studies, vol. 6, no. 1 (Spring):1-22.
Fama, Eugene F., and Kenneth R. French. 1992. "The CrossSection of Expected Stock Returns." Journal of Finance, vol. 47, no. 2 (June):427-465.

. 1993. "Common Risk Factors in the Returns on Stocks and Bonds." Journal of Financial Economics, vol. 33, no. 1 (February):3-56.

___ 1996. "Multifactor Explanations of Asset Pricing Anomalies." Journal of Finance, vol. 51, no. 1 (March):55-84.

___ 1997. "Industry Costs of Equity." Journal of Financial Economics, vol. 43, no. 2 (February):153-193.

French, Kenneth R. 2008. "Fama-French Factors" (http://mba. tuck.dartmouth.edu/pages / faculty / ken.french / data_ library.html).

Getmansky, Mila, Andrew W. Lo, and Igor Makarov. 2004. “An Econometric Model of Serial Correlation and Illiquidity in Hedge Fund Returns." Journal of Financial Economics, vol. 74, no. 3 (December):529-609.

Gibbons, Michael R., Stephen A. Ross, and Jay Shanken. 1989. "A Test of the Efficiency of a Given Portfolio." Econometrica, vol. 57, no. 5 (September):1121-1152.

Goetzmann, William N., and Roger G. Ibbotson. 1994. “Do Winners Repeat? Patterns in Mutual Fund Performance." Journal of Portfolio Management, vol. 20, no. 2 (Winter):9-18.

Grinblatt, Mark, and Sheridan Titman. 1992. "The Persistence of Mutual Fund Performance." Journal of Finance, vol. 47, no. 5 (December):1977-1984.

Hartzell, Jay, Tobias Mühlhofer, and Sheridan Titman. 2007. "Alternative Benchmarks for Evaluating REIT Mutual Fund Performance." Working paper, University of Texas at Austin (29 October).

Hendricks, D., J. Patel, and R. Zeckhauser. 1993. "Hot Hands in Mutual Funds: Short-Run Persistence of Relative Performance, 1974-1988." Journal of Finance, vol. 48, no. 1 (March):93-130.

Hong, Harrison, and Jeremy C. Stein. 1999. "A Unified Theory of Underreaction, Momentum Trading, and Overreaction in Asset Markets." Journal of Finance, vol. 54, no. 6 (December):2143-2184.

Hong, Harrison, Terence Lim, and Jeremy C. Stein. 2000. “Bad News Travels Slowly: Size, Analyst Coverage, and the Profitability of Momentum Strategies." Journal of Finance, vol. 55, no. 1 (February):265-295.

Jegadeesh, Narasimhan, and Sheridan Titman. 1993. "Returns to Buying Winners and Selling Losers: Implications for Stock Market Efficiency." Journal of Finance, vol. 48, no. 1 (March):65-91. 
Jensen, Michael C. 1969. "Risk, the Pricing of Capital Assets, and the Evaluation of Investment Portfolios." Journal of Business, vol. 42, no. 2 (April):167-247.

Kallberg, Jarl G., Crocker L. Liu, and Charles Trzcinka. 2000. "The Value Added from Investment Managers: An Examination of Funds of REITs." Journal of Financial and Quantitative Analysis, vol. 35, no. 3 (September):387-408.

Karolyi, G. Andrew, and Anthony B. Sanders. 1998. "The Variation of Economic Risk Premiums in Real Estate Returns." Journal of Real Estate Finance and Economics, vol. 17, no. 3 (November):245-262.

Lakonishok, Josef, Andrei Schleifer, and Robert W. Vishny. 1994. "Contrarian Investment, Extrapolation, and Risk." Journal of Finance, vol. 49, no. 5 (December):1541-1578.

Lin, Crystal Yan, and Kenneth Yung. 2004. "Real Estate Mutual Funds: Performance and Persistence." Journal of Real Estate Research, vol. 26, no. 1 (January):69-93.

Lintner, John. 1965. "The Valuation of Risk Assets and the Selection of Risky Investments in Stock Portfolios and Capital Budgets." Review of Economics and Statistics, vol. 47, no. 1 (February):13-37.

Merton, R.C. 1973. "An Intertemporal Capital Asset Pricing Model." Econometrica, vol. 41, no. 5 (September):867-887.

Moskowitz, Tobias J., and Mark Grinblatt. 1999. “Do Industries Explain Momentum?" Journal of Finance, vol. 54, no. 4 (August):1249-1290.
Mossin, J. 1966. “Equilibrium in a Capital Asset Market." Econometrica, vol. 34, no. 4 (October):768-783.

Pastor, Lubos, and Robert F. Stambaugh. 2003. "Liquidity Risk and Expected Stock Returns." Journal of Political Economy, vol. 111, no. 3 (June):642-685.

Peterson, James D., and Cheng-Ho Hsieh. 1997. “Do Common Risk Factors in the Returns on Stocks and Bonds Explain Returns on REITs?" Real Estate Economics, vol. 25, no. 2 (June):321-345.

Ross, Stephen A. 1976. "The Arbitrage Theory of Capital Asset Pricing." Journal of Economic Theory, vol. 13, no. 3 (December):341-360.

Ross, Stephen A., and Randall C. Zisler. 1991. “Risk and Return in Real Estate." Journal of Real Estate Finance and Economics, vol. 4, no. 2 (June):175-190.

Sharpe, William F. 1964. "Capital Asset Prices: A Theory of Market Equilibrium under Conditions of Risk." Journal of Finance, vol. 19, no. 3 (September):425-442.

Smith, Keith V., and David Shulman. 1976. "Institutions Beware: The Performance of Equity Real Estate Investment Trusts." Financial Analysts Journal, vol. 32, no. 5 (September/October):61-66.

Titman, Sheridan, and Arthur Warga. 1986. "Risk and the Performance of Real Estate Investment Trusts: A Multiple Index Approach." AREUEA Journal, vol. 14, no. 3:414-431.

Vayanos, Dimitri, and Paul Woolley. 2008. "An Institutional Theory of Momentum and Reversal." Working paper (22 November): http://ssrn.com/abstract $=1305671$. 
Copyright of Financial Analysts Journal is the property of $C F A$ Institute and its content may not be copied or emailed to multiple sites or posted to a listserv without the copyright holder's express written permission. However, users may print, download, or email articles for individual use. 